Louisiana State University

LSU Digital Commons

8-1-2010

\title{
Effect of overall charge and charge distribution on cellular uptake, distribution and phototoxicity of cationic porphyrins in HEp2 cells
}

Timothy J. Jensen

Louisiana State University

M. Graça H. Vicente

Louisiana State University

Raymond Luguya

Louisiana State University

Jolanna Norton

Louisiana State University

Frank R. Fronczek

Louisiana State University

See next page for additional authors

Follow this and additional works at: https://digitalcommons.Isu.edu/chemistry_pubs

\section{Recommended Citation}

Jensen, T., Vicente, M., Luguya, R., Norton, J., Fronczek, F., \& Smith, K. (2010). Effect of overall charge and charge distribution on cellular uptake, distribution and phototoxicity of cationic porphyrins in HEp2 cells. Journal of Photochemistry and Photobiology B: Biology, 100 (2), 100-111. https://doi.org/10.1016/ j.jphotobiol.2010.05.007

This Article is brought to you for free and open access by the Department of Chemistry at LSU Digital Commons. It has been accepted for inclusion in Faculty Publications by an authorized administrator of LSU Digital Commons. For more information, please contact ir@lsu.edu. 
Authors

Timothy J. Jensen, M. Graça H. Vicente, Raymond Luguya, Jolanna Norton, Frank R. Fronczek, and Kevin M. Smith 
Louisiana State University

LSU Digital Commons

8-1-2010

\section{Effect of overall charge and charge distribution on cellular uptake, distribution and phototoxicity of cationic porphyrins in HEp2 cells}

Timothy J. Jensen

Louisiana State University

M. Graça H. Vicente

Louisiana State University

Raymond Luguya

Louisiana State University

Jolanna Norton

Louisiana State University

Frank R. Fronczek

Louisiana State University

See next page for additional authors

Follow this and additional works at: https://digitalcommons.Isu.edu/chemistry_pubs

\section{Recommended Citation}

Jensen, T., Vicente, M., Luguya, R., Norton, J., Fronczek, F., \& Smith, K. (2010). Effect of overall charge and charge distribution on cellular uptake, distribution and phototoxicity of cationic porphyrins in HEp2 cells. Journal of Photochemistry and Photobiology B: Biology, 100 (2), 100-111. https://doi.org/10.1016/ j.jphotobiol.2010.05.007

This Article is brought to you for free and open access by the Department of Chemistry at LSU Digital Commons. It has been accepted for inclusion in Faculty Publications by an authorized administrator of LSU Digital Commons. For more information, please contact ir@lsu.edu. 
Authors

Timothy J. Jensen, M. Graça H. Vicente, Raymond Luguya, Jolanna Norton, Frank R. Fronczek, and Kevin M. Smith 


\title{
Effect of Overall Charge and Charge Distribution on Cellular Uptake, Distribution and Phototoxicity of Cationic Porphyrins in HEp2 Cells
}

\author{
Timothy J. Jensen, M. Graça H. Vicente ${ }^{1}$, Raymond Luguya, Jolanna Norton, Frank R \\ Fronczek, and Kevin M. Smith \\ Department of Chemistry, Louisiana State University, Baton Rouge LA, 70803, USA
}

\begin{abstract}
Five cationic porphyrins bearing one to four $-\mathrm{N}\left(\mathrm{CH}_{3}\right)_{3}{ }^{+}$groups linked to the $p$-phenyl positions of $5,10,15,20$-tetraphenylporphyrin (TPP) were synthesized in order to study the effect of overall charge and its distribution on the cellular uptake, phototoxicity and intracellular localization using human carcinoma HEp2 cells. The di-cationic porphyrins DADP-o and DADP-a accumulated the most within cells and preferentially localize within vesicular compartments and in mitochondria. Of these two only DADP-a was phototoxic to the cells $\left(\mathrm{IC}_{50}=3 \mu \mathrm{M}\right.$ at $\left.1 \mathrm{~J} / \mathrm{cm}^{2}\right)$. The monocationic porphyrin MAP was found to be the most phototoxic of the series, and it localized mainly in lipid membranes, including the plasma membrane, ER, mitochondria, and Golgi. Both the tricationic porphyrin TRAP and the tetra-cationic porphyrin TEAP localized subcellularly mainly in the mitochondria, but of the two only TEAP showed moderate phototoxicity $\left(\mathrm{IC}_{50}=\sim 8 \mu \mathrm{M}\right.$ at $1 \mathrm{~J} /$ $\mathrm{cm}^{2}$ ). Our results suggest that MAP is the most promising PDT photosensitizer, and that both DADP-o and TRAP might find application as transport vehicles for therapeutics into cells.
\end{abstract}

\section{Keywords}

cationic porphyrin; PDT; cytotoxicity; cellular uptake; subcellular localization

\section{Introduction}

\begin{abstract}
Porphyrins and their derivatives have been extensively studied in the past decades for application as sensitizers in photodynamic therapy (PDT) $[1,2]$ and, more recently, in the boron neutron capture therapy (BNCT) [3,4] of tumors. PDT and BNCT are both localized therapeutic modalities that involve the activation of a non-toxic tumor-localized sensitizer with red light (in PDT) or with low-energy neutrons (in BNCT). The main cytotoxic species formed in PDT is believed to be highly transient ${ }^{1} \mathrm{O}_{2}$, while in BNCT the high linear energy transfer particles ${ }^{4} \mathrm{He}^{2+}$ and ${ }^{7} \mathrm{Li}^{3+}$ are generated upon capture of a neutron by a ${ }^{10} \mathrm{~B}$ nucleus. Since the mean distances of travel through tissue of these species are very short (less than a cell diameter), both PDT and BNCT have the potential to be highly selective for malignant tissue, thus minimizing the treatment side effects. Among all proposed sensitizers, cationic porphyrin derivatives have received special attention since they can potentially interact with
\end{abstract}

\footnotetext{
(C) 2010 Elsevier B.V. All rights reserved.

${ }^{1}$ Corresponding author. Phone: (225) 578 7405, Fax: (225) 578 3458, vicente@1su.edu .
}

Publisher's Disclaimer: This is a PDF file of an unedited manuscript that has been accepted for publication. As a service to our customers we are providing this early version of the manuscript. The manuscript will undergo copyediting, typesetting, and review of the resulting proof before it is published in its final citable form. Please note that during the production process errors may be discovered which could affect the content, and all legal disclaimers that apply to the journal pertain. 
anionic DNA and RNA via external binding and/or intercalation, thus causing efficient cell destruction upon irradiation [5-9]. In addition, cationic porphyrins have also been used in the photoinactivation of bacteria (both Gram-positive and Gram-negative) [10-14], viruses [15-17] and other pathogens [18-23]. Positively-charged porphyrins are believed to electrostatically interact with the negative charges present on tumor cell membranes and bacterial surfaces, facilitating their penetration through membranes and consequently their PDT efficacy [24]. Furthermore, cationic porphyrins have been shown to bind to anionic regions on proteins, such as human serum albumin (HAS), and this might play an important role in their transport and preferential accumulation in tumor tissue [25,26]. In addition to targeting plasma membranes [27-30], the cell mitochondria [31-34], lysosomes [33-36], ER [34,37] and nuclei [38] are important primary and/or secondary (upon PDT-induced relocalization) subcellular targets for cationic porphyrins. The number and distribution of the positive charges about the porphyrin macrocycle is known to affect their preferential sites of localization and photodynamic efficacy [27,33,39-41]. Amphiphilic molecules containing both hydrophobic and hydrophilic (charged) sites at the macrocycle periphery generally display higher biological efficacy, possibly because of their enhanced affinity for lipid/aqueous interfaces and consequently improved membrane permeability.

In this study, we examined the role of increasing cationic charge in the form of sequential $\mathrm{N}-\left(\mathrm{CH}_{3}\right)_{3}{ }^{+}$moieties added to a 5,10,14,20-tetraphenylporphyrin (TPP) macrocycle and their distribution, on cellular uptake, intracellular localization, and on phototoxicity.

\section{Experimental}

All solvents and starting materials were purchased from Fisher Scientific or from Sigma Aldrich, and were used without further purification. Reactions were monitored by thin layer chromatography and spectrophotometry. Electronic absorption spectra were measured using a Perkin Elmer Lambda 35 spectrophotometer and fluorescence spectra using a Perkin Elmer LS55 luminescence spectrometer. ${ }^{1} \mathrm{H}$ NMR spectra were obtained in deuterochloroform or acetone- $\mathrm{d}_{6}$ solution, using a Brucker 250 or $400 \mathrm{MHz}$ spectrometer; chemical shifts are expressed in ppm relative to chloroform $(7.26 \mathrm{ppm})$ and/or TMS (0 $\mathrm{ppm})$. Mass spectra were obtained at the mass spectrometry facility at Ohio State University, Ohio, USA. The synthesis of 5-mono-, 5,10-bis-, 5,15-bis- and 5,10,15-tris-(4aminophenyl)porphyrins have been previously reported by us [42]. We have also reported the preparation of 5,10-di[(4-(N-trimethylaminophenyl)-15,20-diphenylprophyrin (DADP-a) and 5,15-di[(4-(N-trimethylaminophenyl)-10,20-diphenylprophyrin (DADP-o) [33].

For the cell culture experiments, all tissue culture media and reagents were obtained from Invitrogen. Human HEp2 cells were obtained from ATCC and maintained in a 50:50 mixture of DMEM:Advanced MEM containing 5\% FBS. The cells were sub-cultured biweekly to maintain sub-confluent stocks.

\subsection{5-[4-(N-trimethylaminophenyl)-10,15,20-triphenylporphyrin (MAP)}

The title compound was prepared using a similar method to that previously described in literature (the alkylation reaction was performed at room temperature overnight rather than at $45^{\circ} \mathrm{C}$ for $5 \mathrm{~h}$, and diisopropylamine was used as co-solvent) and its spectroscopic data were in agreement with these reports [43,44].

\subsection{5,10,15-Tris[4-(N-trimethylaminophenyl)-20-phenylporphyrin (TRAP)}

5,10,15-Tris(4-aminophenyl)-20-phenylporphyrin ( $24 \mathrm{mg}, 0.0365 \mathrm{mmol}$ ), diisopropylamine $(0.06 \mathrm{~mL}, 0.428 \mathrm{mmol})$ and methyl iodide $(0.6 \mathrm{~mL}, 9.638 \mathrm{mmol})$ were dissolved in $1.8 \mathrm{~mL}$ of dry DMF under nitrogen. The mixture was allowed to stir at room temperature over 4 days and upon addition of acetone a solid precipitated. The solid material was filtered and 
washed with acetone and dichloromethane to remove impurities. The solid material collected was dried to give $17 \mathrm{mg} \mathrm{(40 \% )} \mathrm{of} \mathrm{the} \mathrm{alkylated} \mathrm{title} \mathrm{compound;} \mathrm{MS} \mathrm{(ESI)} \mathrm{m/z}$ $263.03\left(\mathrm{M}^{+}\right) ;{ }^{1} \mathrm{H}-\mathrm{NMR}\left(\left(\mathrm{CD}_{3}\right)_{2} \mathrm{SO}\right) \delta \mathrm{ppm}:-2.96(\mathrm{br}, 2 \mathrm{H}) 3.92(\mathrm{~s}, 18 \mathrm{H}), 7.85(\mathrm{~m}, 3 \mathrm{H})$, $8.21(\mathrm{~m}, 2 \mathrm{H}), 8.43(\mathrm{~d} \mathrm{~J}=9.1 \mathrm{~Hz}, 6 \mathrm{H}), 8.50(\mathrm{~d} J=9.0 \mathrm{~Hz}, 6 \mathrm{H}) 8.87(\mathrm{~m}, 8 \mathrm{H})$. UV-Vis (Ethanol) $\lambda_{\max }: 412 \mathrm{~nm}(\varepsilon 406,000), 510(16,200), 543(5,800), 586(4,900)$ and $642(2,400)$. Anal. Calcd for $\mathrm{C}_{53} \mathrm{H}_{54} \mathrm{~N}_{7} \mathrm{I}_{3}\left(\mathrm{H}_{2} \mathrm{O}\right)_{3 / 2}: \mathrm{C}, 51.62 ; \mathrm{H}, 4.99 ; \mathrm{N}, 7.96$. Found: $\mathrm{C}, 51.30 ; \mathrm{H}, 4.72 ; \mathrm{N}$, 7.61 .

\subsection{5,15,10,20-Tetrakis[4-(N-trimethylaminophenyl)-porphyrin (TEAP)}

5,10,15,20-Tetrakis(4-(aminophenyl)porphyrin (20 mg, $0.297 \mathrm{mmol}$ ), diisopropylamine $(0.08 \mathrm{~mL}, 0.571 \mathrm{mmol})$ and methyl iodide $(0.28 \mathrm{~mL}, 4.498 \mathrm{mmol})$ were dissolved in $0.5 \mathrm{~mL}$ of dry DMF and stirred at room temperature over 4 days under argon. Upon addition of acetone a solid precipitated which was filtered and extensively washed with acetone and dichloromethane and then dried to give $29 \mathrm{mg}$ (72\%) of the title product; MS (ESI) $\mathrm{m} / \mathrm{z}$ $211.56\left(\mathrm{M}^{+}\right) ;{ }^{1} \mathrm{H}-\mathrm{NMR}\left(\left(\mathrm{CD}_{3}\right)_{2} \mathrm{SO}\right) \delta \mathrm{ppm}:-2.97(\mathrm{br}, 2 \mathrm{H}) 3.93(\mathrm{~s}, 18 \mathrm{H}), 8.43(\mathrm{~d} J=9.2 \mathrm{~Hz}$, $8 \mathrm{H}), 8.49(\mathrm{~d} J=9.1 \mathrm{~Hz}, 8 \mathrm{H}) 8.87(\mathrm{~s}, 8 \mathrm{H})$. UV-Vis (Ethanol) $\lambda_{\max }: 412 \mathrm{~nm}(\varepsilon 300,000), 509$ $(16,400), 542(6,300), 586(5,500)$ and $642(2,600)$. Anal. Calcd for $\mathrm{C}_{56} \mathrm{H}_{63} \mathrm{~N}_{8} \mathrm{I}_{4}\left(\mathrm{H}_{2} \mathrm{O}\right)_{12}: \mathrm{C}$, 42.77; H, 5.58; N, 7.13. Found: C, 42.68; H, 4.36; N, 7.11.

\subsection{Crystal structure}

The crystal structure of DADP-o hydrate was determined, using data collected at $\mathrm{T}=105 \mathrm{~K}$ to $\theta=22.4^{\circ}$ with MoK $\alpha$ radiation on a Nonius KappaCCD diffractometer. Crystal data: $\left[\mathrm{C}_{50} \mathrm{H}_{46} \mathrm{~N}_{6}\right] \mathrm{I}_{2} .2 \mathrm{H}_{2} \mathrm{O}$, orthorhombic space group Pbca, $\mathrm{a}=9.139(14), \mathrm{b}=12.431(8), \mathrm{c}=$ 40.15(5) $\AA, \mathrm{V}=4561(9) \AA^{3}, \mathrm{Z}=4, \mathrm{R}=0.104\left(\mathrm{~F}^{2}>2 \sigma\right), \mathrm{Rw}=0.227\left(\right.$ all $\left.\mathrm{F}^{2}\right)$ for 2408 unique data and 111 refined parameters. Crystal quality was limited, and only the iodine could be refined as anisotropic. Three group isotropic displacement parameters were refined for $\mathrm{C}$ and $\mathrm{N}$ atoms. The $\mathrm{N}\left(\mathrm{CH}_{3}\right)_{3}$ groups are disordered into two conformations, and water $\mathrm{H}$ atoms could not be located. CCDC 770959.

\subsection{Time-dependent cellular uptake}

The human HEp2 cells were maintained in a 50:50 mix of aMEM:Advanced MEM + 5\% Fetal Bovine Serum (FBS) in a humidified, $5 \% \mathrm{CO}_{2}$ incubator at $37^{\circ} \mathrm{C}$. HEp2 cells were seeded at 10,000 cells per well in a 96 well plate and allowed to attach overnight. Porphyrin stocks were prepared in DMSO at $10 \mathrm{mM}$ and diluted ten fold into DMSO before diluting $100 \mathrm{X}$ into medium (giving $10 \mu \mathrm{M}$ porphyrin and $1 \% \mathrm{DMSO}$ ). The cells were then exposed to porphyrin for specific periods of time. At the end of the incubation time, the loading medium was removed, the cells were washed with PBS, and solubilized with $0.25 \%$ Triton X-100 in PBS. The intracellular accumulation of porphyrin was determined by measuring the compound's fluorescence emission of the porphyrin using a FluoStar Optima plate reader (BMG, Chicago,IL) and excitation/emission wavelengths of $410 \mathrm{~nm}$ and $650 \mathrm{~nm}$, respectively. The cell numbers were measured using the CyQuant Cell Proliferation Assay (Molecular Probes) and the uptake was expressed in terms of $\mu \mathrm{M}$ compound per 1000 cells.

\subsection{Dark Cytotoxicity}

The HEp2 cells were plated as described above and allowed to attach overnight. The porphyrins were then added as described for the uptake assay at concentrations ranging from $500 \mu \mathrm{M}$ to $31 \mu \mathrm{M}$, and allowed to incubate for 24 hours. Cell toxicity was measured using the Cell Titer Blue assay (Promega) as per manufacturer's instructions, by reading the fluorescence at 520/584nm using a BMG FLUOstar plate reader. The signal was normalized to $100 \%$ viable (untreated) cells and $0 \%$ viable (treated with $0.2 \%$ saponin from Sigma) cells. 


\subsection{Phototoxicity}

The HEp2 cells were prepared as described above for the dark cytotoxicity assay, treated with porphyrin concentrations of $0,1.25,2.5,5$, and $10 \mu \mathrm{M}$ and incubated for $24 \mathrm{~h}$. The medium was removed and the cells washed twice with growth medium and fed $100 \mu \mathrm{L}$ of medium containing $50 \mathrm{mM}$ HEPES pH 7.4. The cells were then placed on ice and exposed to light from a $100 \mathrm{~W}$ halogen lamp filtered through a $610 \mathrm{~nm}$ long pass filter (Chroma) for 20 minutes. An inverted plate lid filled with cold water to a depth of $5 \mathrm{~mm}$ acted as an IR filter. The total light dose was approximately $1 \mathrm{~J} / \mathrm{cm}^{2}$. The cells were returned to the incubator overnight and assayed for toxicity as described above for the dark cytotoxicity experiment.

\subsection{Intracellular localization}

The HEp2 cells were seeded onto Lab-Tek II, 2-chamber coverglass and incubated for 24 hours. Compound was then added to a final concentration of $10 \mu \mathrm{M}$. Cells were incubated in the dark for 30 minutes to 24 hours, then washed with drug-free medium and fed medium containing $50 \mathrm{mM}$ HEPES $\mathrm{pH}$ 7.2. Coverslips were examined using a Zeiss Axiovert 200M inverted fluorescence microscope fitted with standard FITC and Texas Red filter sets (Chroma Technologies, Rockingham,VT). For co-localization experiments, organelle specific stains were obtained from Molecular Probes: lysosomes were visualized with LysoSensor at $50 \mathrm{nM}$, ERTracker or DIOC6 were used to visualize the ER (50 nM or $5 \mu \mathrm{M}$ respectively), Mitochondria were stained using MitoTracker at $250 \mathrm{nM}$, and Golgi were visualized using BODIPY-Ceramide at $250 \mathrm{nM}$. The organelle tracers were diluted in medium and the cells were incubated concurrently with porphyrin and tracers for 30 minutes before washing and microscopy. Fluorescence microscopy was performed using a Zeiss Axiovert 200 inverted fluorescence microscope fitted with standard FITC and Texas Red filter sets (Chroma). The images were aquired with a Zeiss Axiocam MRM CCD camera fitted to the microscope.

\section{Results}

\subsection{Syntheses and structural characterization}

The five cationic porphyrins (Figure 1) bearing one (MAP), two adjacent (DADP-a), two opposite (DADP-o), three (TRAP) or four (TEAP) positive charges were synthesized by direct nitration of TPP using $\mathrm{NaNO}_{2} / \mathrm{TFA}$, as previously reported [42]. Reduction of the nitro groups to amino with $\mathrm{SnCl}_{2} / \mathrm{HCl}$ gave the corresponding amino-TPP derivatives in 21$54 \%$ overall yields. The quaternization of the amino groups was accomplished using methyl iodide in the presence of diisopropylamine, in 40-72\% yields. All porphyrins were characterized by ${ }^{1} \mathrm{H}-\mathrm{NMR}$, MS, UV-Vis, and elemental analyses, and in the case of DADP-o by X-ray crystallography (Figure 2).

\subsection{Time-dependent uptake}

The cellular uptake studies using this series of cationic porphyrins (Figure 1) showed remarkably different uptake patterns, as shown in Figure 3. Among this series of porphyrins, DADP-a accumulated the most within cells, followed by its regioisomer DADP-o. On the other hand, the tetra-cationic TEAP was found to accumulate the least at long time points (> $8 \mathrm{~h}$ ), whereas as shorter time points MAP was the least taken-up by cells. While the cellular uptake of TRAP and TEAP reached a plateau after $\sim 4 \mathrm{~h}$, that of MAP, DADP-a and DADPo continually increased overtime during the period investigated, although the amount of MAP found within cells after $24 \mathrm{~h}$ was approximately one fourth that of DADP-a. 


\subsection{Cytotoxicity}

The dark and light cytotoxic effects of this series of cationic porphyrins varied considerably with the overall charge and its distribution. As seen in Figure 4, DADP-a showed the highest dark toxicity with a determined $\mathrm{IC}_{50}$ of $25 \mu \mathrm{M}$, followed by MAP $(75 \mu \mathrm{M})$, TRAP $(175$ $\mu \mathrm{M})$, TEAP $(230 \mu \mathrm{M})$ and DADP-o $(445 \mu \mathrm{M})$. It is interesting to note the significantly higher dark cytotoxic effect of DADP-a in comparison with the other porphyrins, while DADP-o was found to be the least toxic in the dark, even though its subcellular accumulation was only slightly lower than that of DADP-a. Therefore cytotoxicity does not appear to be directly related to the amount of porphyrin sequestered within the cells.

On the other hand, upon activation with low light dose $\left(1 \mathrm{~J} / \mathrm{cm}^{2}\right)$ MAP was found to be the most phototoxic with a calculated $\mathrm{IC}_{50}$ of $2 \mu \mathrm{M}$, closely followed by DADP-a at $3 \mu \mathrm{M}$ (Figure 5). TEAP was moderately phototoxic with an $\mathrm{IC}_{50}$ of $8 \mu \mathrm{M}$, while DADP-o and TRAP showed no phototoxicity at the concentrations tested (up to $10 \mu \mathrm{M}$ ).

\subsection{Intracellular localization}

The subcellular localization of the cationic porphyrins was investigated using fluorescence microscopy and the results obtained are shown in Figures 6-11. The organelle specific fluorescent probes ERTracker (ER), LysoSensor Green (lysosomes), Mitotracker Green (mitochondria) and BODIPY Ceramide (Golgi) were used in the overlay experiments (the orange yellow color indicates colocalization).

MAP was found to localize in the membranous compartments of the cells, including the plasma membrane, ER, mitochondria, and Golgi, as seen in Figure 6. On the other hand, DADP-a (Figure 7) and DADP-o (Figure 8) both showed a preference for mitochondria. However, DADP-a also tended to accumulate in large aggregates, some of which seem to associate with vesicles, such as lysosomes. The tri-cationic TRAP (Figure 9) and tetracationic TEAP (Figure 10) accumulated in vesicles to a lesser degree than DADP-a while still maintained a strong association with the mitochondria.

In a cellular uptake study conducted over time using fluorescence microscopy (data not shown), we observed that MAP and DADP-a both strongly stained the plasma membrane of the cell within 30 minutes (Figure 11). With the exception of DADP-o, all other porphyrins showed some initial association with the plasma membrane before internalization and subsequently mitochondrial localization. In the case of MAP, the staining gradually spread to the interior membranous compartments. On the other hand, for all other porphyrins a punctate pattern appeared, followed by staining of the mitochondria. While DADP-a seemed to form large aggregates or assemblies during internalization before spreading to the mitochondria, and possibly as a consequence the appearance of DADP-o in the mitochondria occurred earlier than with DADP-a.

\section{Discussion}

\subsection{Syntheses}

Several methodologies have been used for the preparation of cationic porphyrins, the most common rely on quaternization of amino- or pyridinium-substituted porphyrins with alkyl halides [33,35,43-45]. Since amino-substituted porphyrins can be readily obtained in multigram amounts by a two-step, one-pot reaction involving direct and selective nitration of the para-phenyl positions of TPP followed by reduction [42], porphyrins in Figure 1 were all prepared using this methodology, followed by quaternization using methyl iodide $[33,43,44]$. The structures of the two regioisomers DADP-a and DADP-o were assigned based on their UV-Vis, ${ }^{1} \mathrm{H}-\mathrm{NMR}$ and crystal structure (Figure 2). DADP-o is a more 
symmetrical molecule, showing only two types of $\beta$-protons in the ${ }^{1} \mathrm{H}$-NMR spectrum $(1: 1$ ratio) rather than three signals as observed for DADP-a (1:2:1 ratio) [33]. Furthermore the absorption bands of DADP-o typically have larger extinction coefficients than those of DADP-a, probably as result from electrostatic repulsion between the two adjacent positive charges and macrocycle distortion in DADP-a. Figure 2 shows the molecular structure of DADP-o. The dication lies on an inversion center in the crystal, and the 24-atom porphyrin core is essentially planar, exhibiting mean deviation $0.03 \AA$ from coplanarity, with a maximum deviation of $0.05(1) \AA$. The two independent phenyl groups form dihedral angles of $64.7(4)^{\circ}$ (substituted) and $58.8(3)^{\circ}$ (unsubstituted) with the porphyrin plane.

Although the hydrophobic character of this series of cationic porphyrins was not determined in this study, we believe it decreases with increasing number of positively charged groups at the porphyrin periphery, as previously observed [30,41], in the order MAP > DADP-o DADP-a > TRAP > TEAP.

\subsection{Cellular Studies}

Our results demonstrate that the biological properties of cationic porphyrins bearing different number and distribution of trimethylammonium groups varies significantly. Cationic charge(s) at the molecule periphery can be used to not only to target cellular membranes, but also intracellular components such as the mitochondria, which are considered one of the most important subcellular sites for targeted therapeutic agents in cancer treatment $[27,34,46,47]$. The number and distribution of cationic groups and the overall molecule charge are known to influence the hydrophobic character of these compounds, as well as their ability for association with potential carriers, interaction with cellular membranes, and ultimately their biological efficacy. MAP, bearing only one cationic group, has a strongly polarized charge distribution and it is believed to have the highest relative hydrophobic character of this series of porphyrins (Figure 1). The cationic group in MAP facilitates binding to the cell plasma membrane, while the predominant hydrophobic nature of the porphyrin allows it to penetrate the lipid membrane, and to other membranous compartments of the cell, as observed by microscopy (Figures 6 and 11). Our results are in agreement with previous studies showing that mono-cationic sensitizers target plasma membranes [28-30]. Therefore, the subcellular distribution of MAP within several biologically significant compartments is believed to be the major cause of its high phototoxicity, the highest of this series of porphyrins, as shown in Figure 5. In addition MAP was found to have the highest ratio ( 38$)$ of dark cytotoxicity/phototoxicity of this series of porphyrins and is therefore the most promising of this series for use as PDT photosensitizer.

DADP-a, bearing two positive charges on adjacent meso-phenyl groups, also has a strongly polarized charge distribution and amphiphilicity, which might be responsible for its significantly higher uptake within cells. Previous studies have suggested that the amphiphilic nature conferred by adjacent cationic charges at the periphery of porphyrin macrocycles facilitate membrane penetration as a consequence of enhanced affinity for lipid/ aqueous interfaces and hydrophobic/hydrophilic interactions [33,36,39-41]. However, DADP-a is also prone to aggregation, which results in large amount of compound accumulating within the cell in addition to mitochondria localization, as observed by microscopy. The large amount of DADP-a accumulated within cells (Figure 3 ) and its partial localization in mitochondria are believed to be the main causes of its observed high phototoxicity (Figure 5). Furthermore, a relatively low ratio ( $\sim 8)$ of dark cytotoxicity/ phototoxicity was found for this porphyrin, thus making it less promising for application in PDT compared with MAP. The high dark toxicity observed for DADP-a could be due to its partial incorporation within cell nuclei, although our microscopy results provide no evidence for penetration of any of the photosensitizers into the cell nucleus. 
While DADP-o (Figure 2) has the same overall charge as DADP-a, its charge distribution is different and consequently we expected different biological activity, as previously reported [33]. While the di-cationic nature of this molecule still facilitates binding to the cell surface and subsequent internalization, its lower amphiphilicity might be the main factor responsible for its lower cellular uptake compared with DADP-a (Figure 3). Furthermore, DADP-o showed no phototoxicity at concentrations up to $10 \mu \mathrm{M}$ and the lowest dark toxicity of this series of porphyrins. Although it is desirable to reduce side effects of a phototherapeutic agent by minimizing its dark toxicity while maximizing its dark cytotoxicity/phototoxicity ratio, the observed low phototoxicity of DADP-o attenuates its usefulness as PDT photosensitizer. However, a potential application of this compound is as delivery vehicle for therapeutic compounds, for example oligonucleotides, to targeted cells (vide infra). It is certainly interesting to note that DADP-o bearing the two positive charges on opposite meso-phenyl rings shows completely different cytotoxicity (Figures 3 and 4) and subcellular distributions (Figure 8) as those observed for DADP-a (Figure 7), indicating that not only charge but also its spatial distribution play a major role in mitochondrial targeting, in agreement with previous reports $[32,33]$. In our previous studies we observed a mitochondrial preference for DADP-a and a lysosomal preference for DADP-o, $30 \mathrm{~min}$ after incubation with Murine L1210 suspension cells [33]. Our present results confirm these findings and further investigate the preferential sites of subcellular localization at both short and long (up to18 h) time points, using human HEp2 adherent cells, revealing the mitochondrial localization of DADP-o as well as the punctate lysosomal signal seen in the previous studies.

TRAP and TEAP, bearing 3 and 4 positive charges, respectively, showed good localization to the mitochondria, as seen in Figures 9 and 10. However they showed significant lower cellular uptake and phototoxicity compared with MAP and DADP-a, probably as a result of decreasing hydrophobic character and amphiphilicity. The low dark-and phototoxicity observed for these compounds, in particular DADP-o and TRAP, along with their strong affinity for the cell mitochondria make them good candidates to act as transport agents for the delivery of therapeutics into cells, and in particular the mitochondria. Indeed several cationic porphyrins, containing either two positive charged groups on opposite sides of the macrocycle or four positive charges symmetrically distributed, have been found to be excellent delivery vehicles for oligonucleotides into cells [48,49]. Nucleic acid-based therapies are limited by the poor penetration of polyanionic and hydrophilic oligonucleotides into cells, and the use of delivery vehicles such as cationic lipids and/or polyamines is often associated with increased toxicity. Cationic porphyrins of low toxicity could be used as an alternative and potentially highly effective method for the delivery of oligonucleotides intracellularly. The combination of cationic charge and lipophilic character has been widely used to facilitate the delivery of peptides and small molecules into cells [50]. Cationic porphyrins such as DADP-o could potentially mimic mitochondrial localization signaling (MLS) sequences that are often characterized by clusters of positively charged amino acids as well as hydrophobic residues, and therefore be used as delivery agents into cell mitochondria. In fact, we have previously reported that cationic porphyrins bearing either a guanidinium or a biguanidinium group were more effective at targeting the cell mitochondria than a porphyrin-MLS conjugate [34].

\section{Conclusions}

A series of cationic porphyrins bearing one to four $-\mathrm{N}\left(\mathrm{CH}_{3}\right)_{3}{ }^{+}$groups was synthesized in good overall yields and their biological properties were investigated in human HEp2 cells. The extent of their cellular uptake was dependent on their amphiphilicity, rather than hydrophobic character. The dark- and photo-toxicity varied greatly among this series of porphyrins; the most phototoxic compound was MAP, followed by DADP-a and TEAP. All 
compounds were found to target the mitochondria as well as, to some extent, the lysosomes. MAP showed a unique affinity for localization in the membranous compartments of the cells and the highest dark/phototoxicity ratio, and therefore is the most promising candidate for PDT applications. On the other hand, DADP-o and TRAP were the least toxic to cells and can therefore find application as delivery agents for therapeutics into human cells, particularly the mitochondria.

\section{Acknowledgments}

The work described was supported by the National Institutes of Health, grant numbers CA132861 (to KMS) and CA139297 (to MGHV).

\section{References}

1. Dougherty TJ, Gomer CJ, Henderson BW, Jori G, Kessel D, Korbelik M, Moan J, Peng Q. Photodynamic therapy. J. Natl. Cancer Inst. 1998; 90:889-905. [PubMed: 9637138]

2. Pandey, RK.; Zheng, G. Porphyrins as photosensitizers in photodynamic therapy. In: Kadish, KM.; Smith, KM.; Guilard, R., editors. The Porphyrin Handbook. Boston: Academic Press; 2000. p. 157-230.

3. Soloway AH, Tjarks W, Barnum BA, Rong FG, Barth RF, Codogni IM, Wilson JG. The chemistry of neutron capture therapy. Chem. Rev. 1998; 98:1515-1562. [PubMed: 11848941]

4. Barth RF, Coderre JA, Vicente MGH, Blue TE. Boron neutron capture therapy of cancer: current status and future prospects. Clin. Cancer Res. 2005; 11:3987-4002. [PubMed: 15930333]

5. McMillin DR, Shelton AH, Bejune SA, Fanwick PE, Wall RK. Understanding binding interactions of cationic porphyrins with B-form DNA. Coord. Chem. Rev. 2005; 249:1451-1459.

6. Mita H, Ohyama T, Tanaka Y, Yamamoto Y. Formation of a complex of 5,10,15,20-tetrakis(Nmethylpyridinium-4-yl)-21H,23H-porphyrin with G-quadruplex DNA. Biochemistry. 2006; 45:6765-6772. [PubMed: 16734413]

7. Wang K, Zhang Z, Wu L, Li Z-Y. Synthesis, and DNA-binding and DNA-photocleavage properties of multiply charged porphyrins. Chemistry \& Biodiversity. 2007; 4:514-522. [PubMed: 17372954]

8. Caminos DA, Durantini EN. Interaction and photodynamic activity of cationic porphyrin derivatives bearing different patterns of charge distribution with GMP and DNA. J. Photochem. Photobiol., A: Chem. 2008; 198:274-281.

9. Jia G, Feng Z, Wei C, Zhou J, Wang X, Li C. Dynamic insight into the interaction between porphyrin and G-quadruplex DNAs: time-resolved fluorescence anisotropy study. J. Physical Chem. B. 2009; 113:16237-16245.

10. Hamblin MR, O'Donnell DA, Murthy N, Contag CH, Hasan T. Rapid control of wound infections by targeted photodynamic therapy monitored by in vivo bioluminescence imaging. Photochem. Photobiol. 2002; 75:51-57. [PubMed: 11837327]

11. Reddi E, Ceccon M, Valduga G, Jori G, Bommer JC, Elisei F, Latterini L, Mazzucato U. Photophysical properties and antibacterial activity of meso-substituted cationic porphyrins. Photochem. Photobiol. 2002; 75:462-470. [PubMed: 12017471]

12. Sol V, Branland P, Chaleix V, Granet R, Guilloton M, Lamarche F, Verneuil B, Krausz P. Amino porphyrins as photoinhibitors of gram-positive and -negative bacteria. Bioorg. Med. Chem. Lett. 2004; 14:4207-4211. [PubMed: 15261271]

13. Lazzeri D, Rovera M, Pascual L, Durantini EN. Photodynamic studies and photoinactivation of Escherichia coli using meso-substituted cationic porphyrin derivatives with asymmetric charge distribution. Photochem. Photobiol. 2004; 80:286-293. [PubMed: 15362952]

14. Ergaieg K, Chevanne M, Cillard J, Seux R. Involvement of both type I and type II mechanisms in Gram-positive and Gram-negative bacteria photosensitization by a meso-substituted cationic porphyrin. Solar Energy. 2008; 82:1107-1117.

15. Trannoy LL, Terpstra FG, de Korte D, Lagerberg JWM, Verhoeven AJ, Brand A, van Engelenburg FAC. Differential sensitivities of pathogens in red cell concentrates to tri-P(4)-photoinactivation. Vox Sanguinis. 2006; 91:111-118. [PubMed: 16907871] 
16. Zupan K, Egyeki M, Toth K, Fekete A, Herenyi L, Modos K, Csik G. Comparison of the efficiency and the specificity of DNA-bound and free cationic porphyrin in photodynamic virus inactivation. J. Photochem. Photobiol., B: Biol. 2008; 90:105-112.

17. Casteel MJ, Jayaraj K, Gold A, Ball LM, Sobsey MD. Photoinactivation of hepatitis A virus by synthetic porphyrins. Photochem. Photobiol. 2004; 80:294-300. [PubMed: 15362943]

18. Rovaldi CR, Pievsky A, Sole NA, Friden PM, Rothstein DM, Spacciapoli P. Photoactive porphyrin derivative with broad-spectrum activity against oral pathogens In vitro. Antimicrob. Agents Chemother. 2000; 44:3364-3367. [PubMed: 11083641]

19. Soukos NS, Ximenez-Fyvie LA, Hamblin MR, Socransky SS, Hasan T. Targeted antimicrobial photochemotherapy. Antimicrob. Agents Chemother. 1998; 42:2595-2601. [PubMed: 9756761]

20. Amor TB, Bortolotto L, Jori G. Porphyrins and related compounds as photoactivatable insecticides. 2. Phototoxic activity of meso-substituted porphyrins. Photochem. Photobiol. 1998; 68:314-318.

21. Cormick MP, Alvarez MG, Rovera M, Durantini EN. Photodynamic inactivation of Candida albicans sensitized by tri- and tetra-cationic porphyrin derivatives. Eur. J. Med. Chem. 2009; 44:1592-1599. [PubMed: 18762356]

22. Bristow C-A, Hudson R, Paget TA, Boyle RW. Potential of cationic porphyrins for photodynamic treatment of cutaneous Leishmaniasis. Photodiagnosis and Photodynamic Therapy. 2006; 3:162167.

23. Kassab K, Amor TB, Jori G, Coppellotti O. Photosensitization of Colpoda inflata cysts by mesosubstituted cationic porphyrins. Photochem. Photobiol. Sci. 2002; 1:560-564. [PubMed: 12659497]

24. Kornguth SE, Kalianke T, Robins HI, Cohen JD, Turski P. Preferential binding of radiolabeled poly-L-lysine to C6 and U87 MG glioblastomas compared to endothelial cells in vitro. Cancer Res. 1989; 49:6390-6395. [PubMed: 2804985]

25. Ma H-M, Chen X, Zhang N, Han Y-Y, Wu D, Du B, Wei Q. Spectroscopic studies on the interaction of a water-soluble cationic porphyrin with proteins. Spectrochim. Acta, Part A: Mol. Biomol. Spectroscopy. 2009; 72A:465-469.

26. Zhou B, Zhang Z, Zhang Y, Li R, Xiao Q, Liu Y, Li Z. Binding of cationic porphyrin to human serum albumin studied using comprehensive spectroscopic methods. J. Pharmac. Sci. 2009; 98:105-113.

27. Kessel D. Correlation between subcellular localization and photodynamic efficacy. J. Porphyrins Phthalocyanines. 2004; 8:1009-1014.

28. Kessel D, Woodburn K, Henderson BW, Chang CK. Sites of photodamage in vivo and in vitro by a cationic porphyrin. Photochem. Photobiol. 1995; 62:875-881. [PubMed: 8570726]

29. Kessel D, Luo Y, Deng Y, Chang CK. The role of subcellular localization in initiation of apoptosis by photodynamic therapy. Photochem. Photobiol. 1997; 65:422-426. [PubMed: 9077123]

30. Kessel D. Relocalization of cationic porphyrins during photodynamic therapy. Photochem. Photobiol. Sci. 2002; 1:837-840. [PubMed: 12659521]

31. Salet C, Moreno G. New trends in photobiology. Photosensitization of mitochondria. Molecular and cellular aspects. J. Photochem. Photobiol., B: Biol. 1990; 5:133-150.

32. Kessel D. Sites of photodamage by the iminium salt of a copper octaethylbenzochlorin. Photochem. Photobiol. 1993; 58:623-626. [PubMed: 8248337]

33. Kessel D, Luguya R, Vicente MGH. Localization and photodynamic efficacy of two cationic porphyrins varying in charge distribution. Photochem. Photobiol. 2003; 78:431-435. [PubMed: 14653572]

34. Sibrian-Vazquez M, Nesterova IV, Jensen TJ, Vicente MGH. Mitochondria-targeting by guanidine- and biguanidine-porphyrin photosensitizers. Bioconjugate Chem. 2008; 19:705-713.

35. Ricchelli F, Franchi L, Miotto G, Borsetto L, Gobbo S, Nikolov P, Bommer JC, Reddi E. Mesosubstituted tetra-cationic porphyrins photosensitize the death of human fibrosarcoma cells via lysosomal targeting. Int. J. Biochem. Cell Biol. 2005; 37:306-319. [PubMed: 15474977]

36. Sibrian-Vazquez M, Jensen TJ, Fronczek FR, Hammer RP, Vicente MGH. Synthesis and characterization of positively charged porphyrin-peptide conjugates. Bioconj. Chem. 2005; 16:852-863. 
37. Sibrian-Vazquez M, Jensen TJ, Hammer RP, Vicente MGH. Peptide-mediated cell transport of water-soluble porphyrin conjugates. J. Med. Chem. 2006; 49:1364-1372. [PubMed: 16480271]

38. Villanueva A. The cationic meso-substituted porphyrins: an interesting group of photosensitizers. J. Photochem. Photobiol. B: Biol. 1993; 18:295-298.

39. Osterloh J, Vicente MGH. Mechanisms of porphyrinoid localization in tumors. J. Porphyrins Phthalocyanines. 2002; 6:305-324.

40. Engelmann FM, Rocha SVO, Toma HE, Araki K, Baptista MS. Determination of n-octanol/water partition and membrane binding of cationic porphyrins. Int. J. Pharmac. 2007; 329:12-18.

41. Engelmann FM, Mayer I, Gabrielli DS, Toma HE, Kowaltowski AJ, Araki K, Baptista MS. Interaction of cationic meso-porphyrins with liposomes, mitochondria and erythrocytes. J. Bioenerg. Biomembranes. 2007; 39:175-185.

42. Luguya R, Jaquinod L, Fronczek FR, Vicente MGH, Smith KM. Synthesis and reactions of meso( $p$-nitrophenyl) porphyrins. Tetrahedron. 2004; 60:2757-2763.

43. Syrbu SA, Semeikin AS, Syrbu TV. Synthesis of tetraphenylporphines containing active groups in phenyl rings. 7. Salts of tetrakis(N,N,N-trimethylaminophenyl) porphines. Khim. Geterot. Soed. 1996; 5:668-671.

44. Chen B, Wu S, Li A, Liang F, Zhou X, Cao X, He Z. Synthesis of some multi- $\beta$-substituted cationic porphyrins and studies on their interaction with DNA. Tetrahedron. 2006; 62:5487-5497.

45. Pandey RK, Shiau F-Y, Smith NW, Dougherty TJ, Smith KM. Syntheses of water-soluble cationic porphyrins and chlorins. Tetrahedron. 1992; 48:7591-7600.

46. Kessel D, Luo Y. Mitochondrial photodamage and PDT-induced apoptosis. J. Photochem. Photobiol. B: Biol. 1998; 42:89-95.

47. Dias N, Bailly C. Drugs targeting mitochondrial functions to control tumor cell growth. Biochem. Pharm. 2005; 70:1-12. [PubMed: 15907809]

48. Kralova J, Dvorak M, Kral V. Novel cationic transport agents for oligonucleoyide delivery into primary leukemic cells. J. Med. Chem. 2003; 46:2049-2056. [PubMed: 12747777]

49. Benimetskaya L, Takle GB, Vilenchik M, Lebedeva I, Miller P, Stein CA. Cationic porphyrins: novel delivery vehicles for antisense oligodeoxynucleotides. Nucleic Acids Res. 1998; 26:5310 5317. [PubMed: 9826753]

50. Carrigan CN, Imperiali B. The engineering of membrane-permeable peptides. Analytical Biochemistry. 2005; 341:290-298. [PubMed: 15907875] 

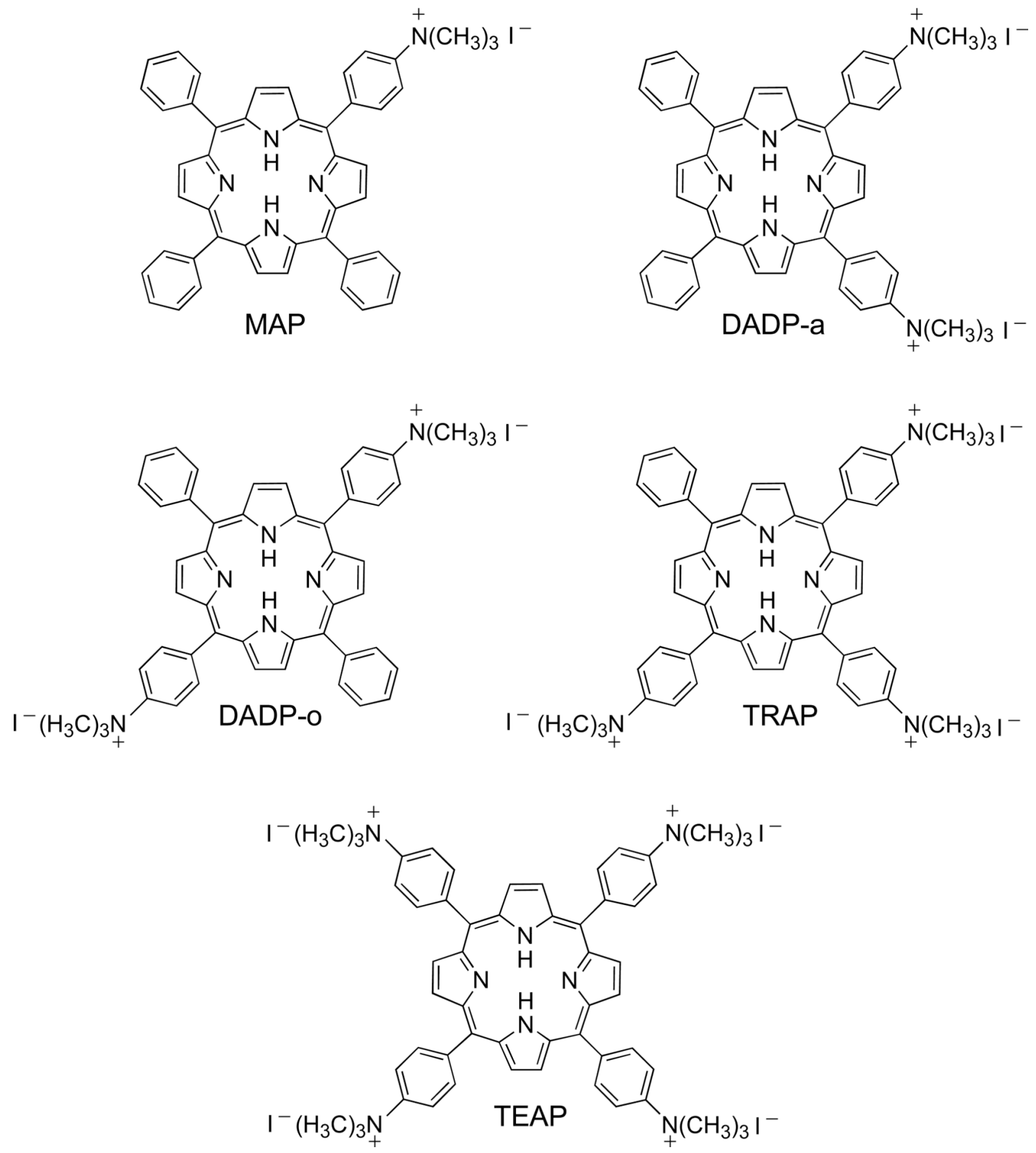

Figure 1.

Structures of MAP, DADP-a, DADP-o, TRAP and TEAP 


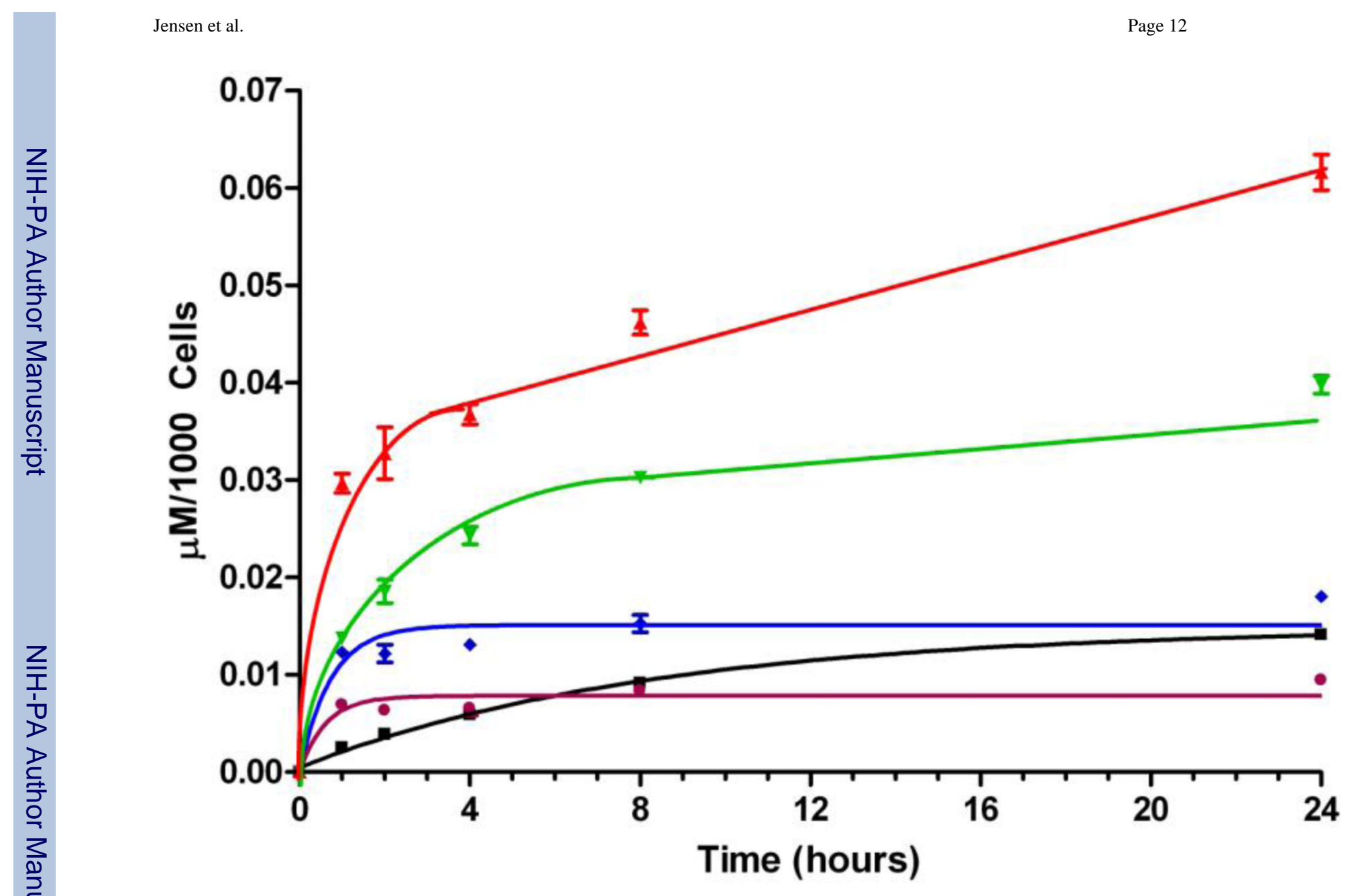

Figure 2.

Structure of the DADP-o dication. 


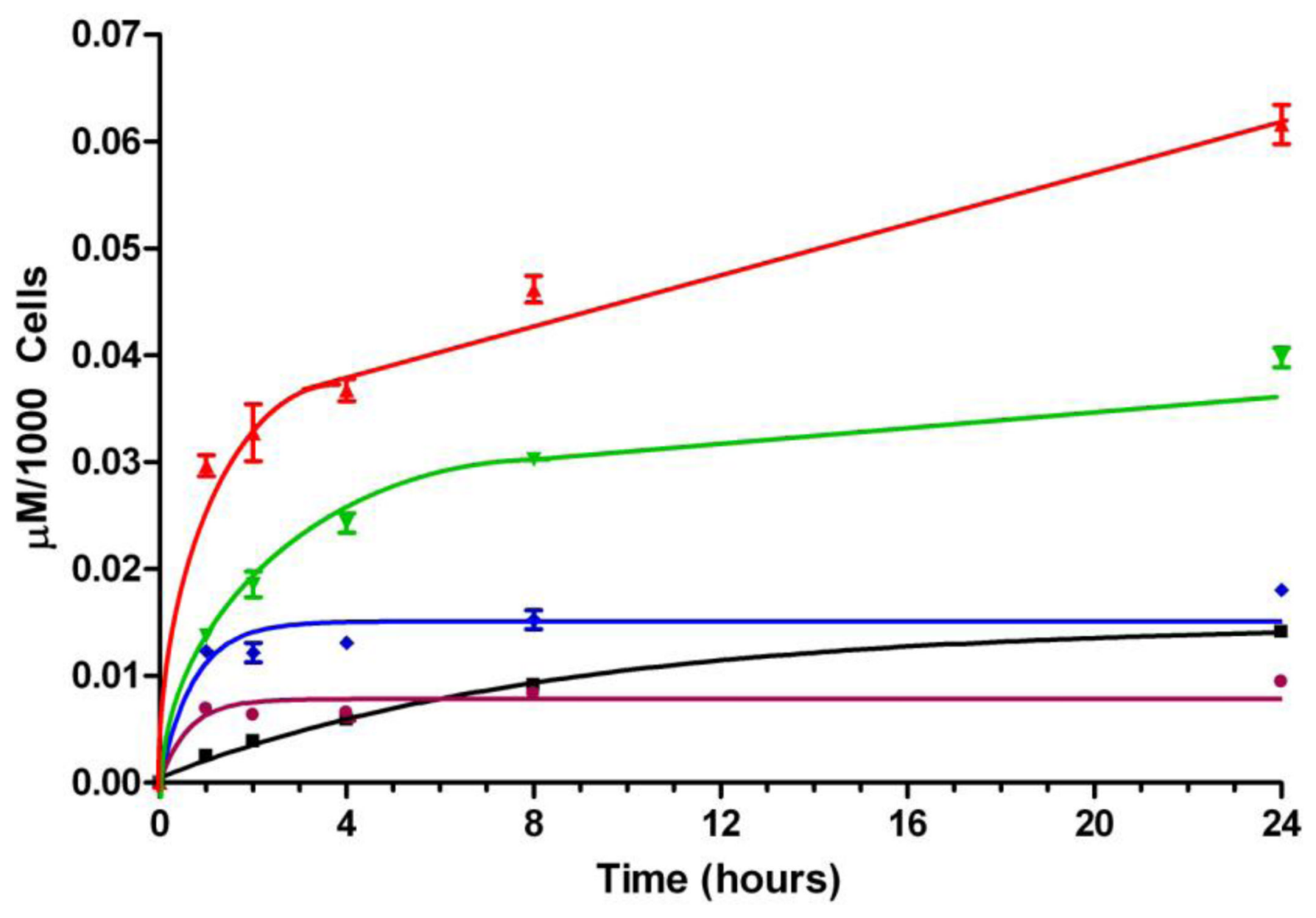

Figure 3.

Time-dependent uptake of cationic porphyrins MAP (black), DADP-a (red), DADP-o (green), TRAP (blue) and TEAP (purple) at $10 \mu \mathrm{M}$ by HEp 2 cells. 


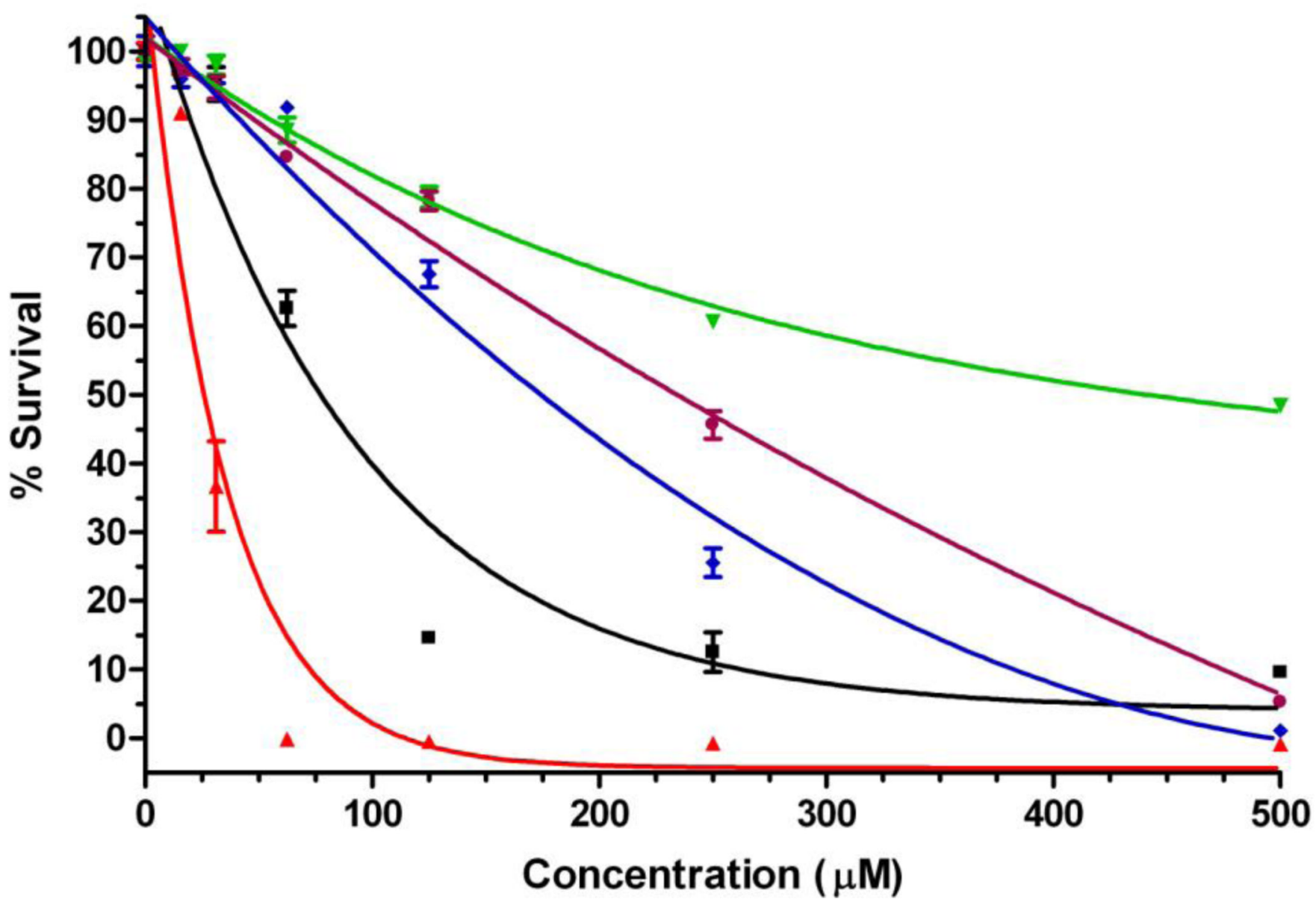

Figure 4.

Dark toxicity of cationic porphyrins MAP (black), DADP-a (red), DADP-o (green), TRAP

(blue) and TEAP (purple) toward HEp2 cells using the CellTiter Blue assay. 


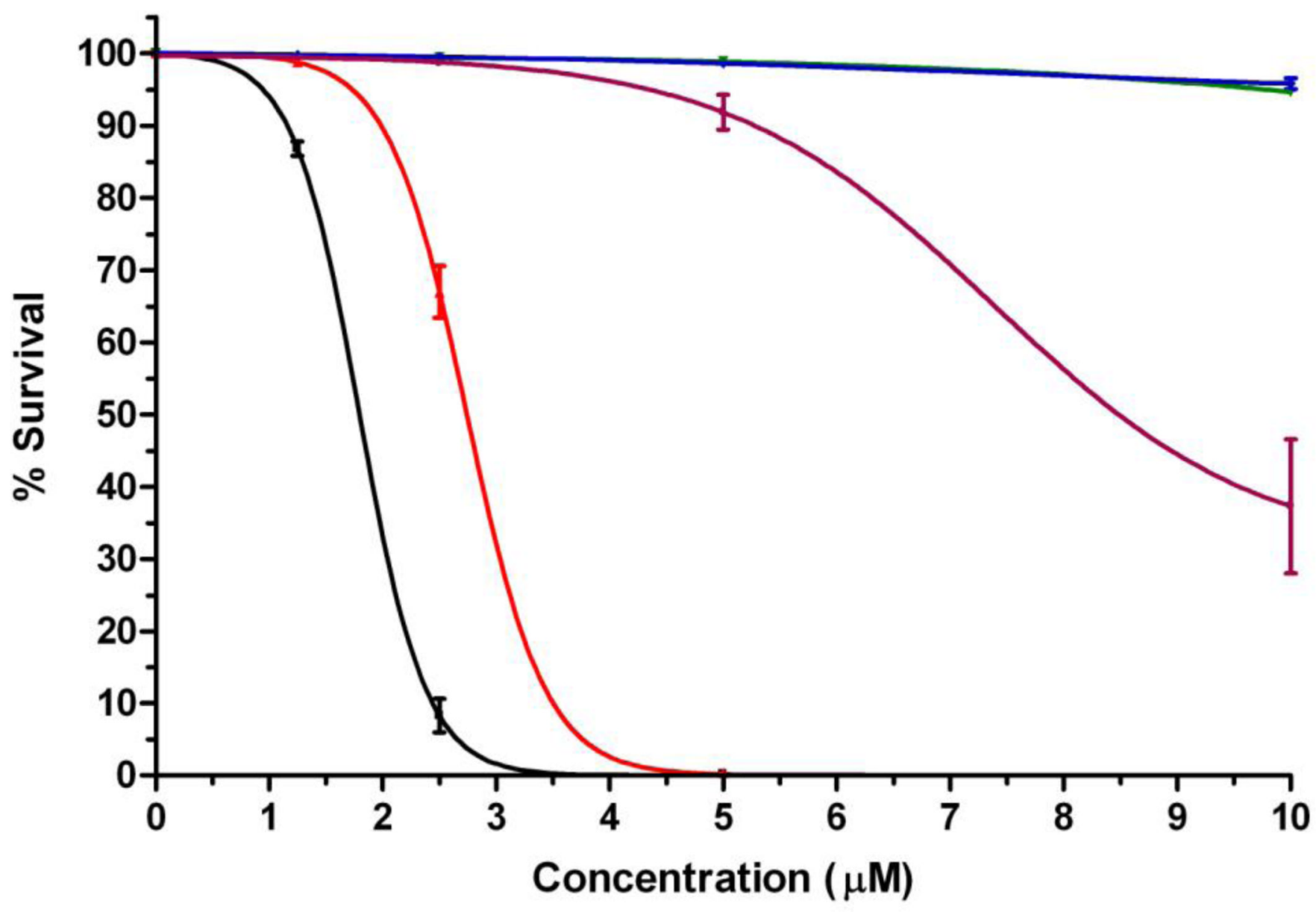

Figure 5.

Phototoxicity of cationic porphyrins MAP (black), DADP-a (red), DADP-o (green), TRAP (blue) and TEAP (purple) toward human HEp2 cells at $1 \mathrm{~J} / \mathrm{cm}^{2}$ light dose using the CellTiter Blue assay. 

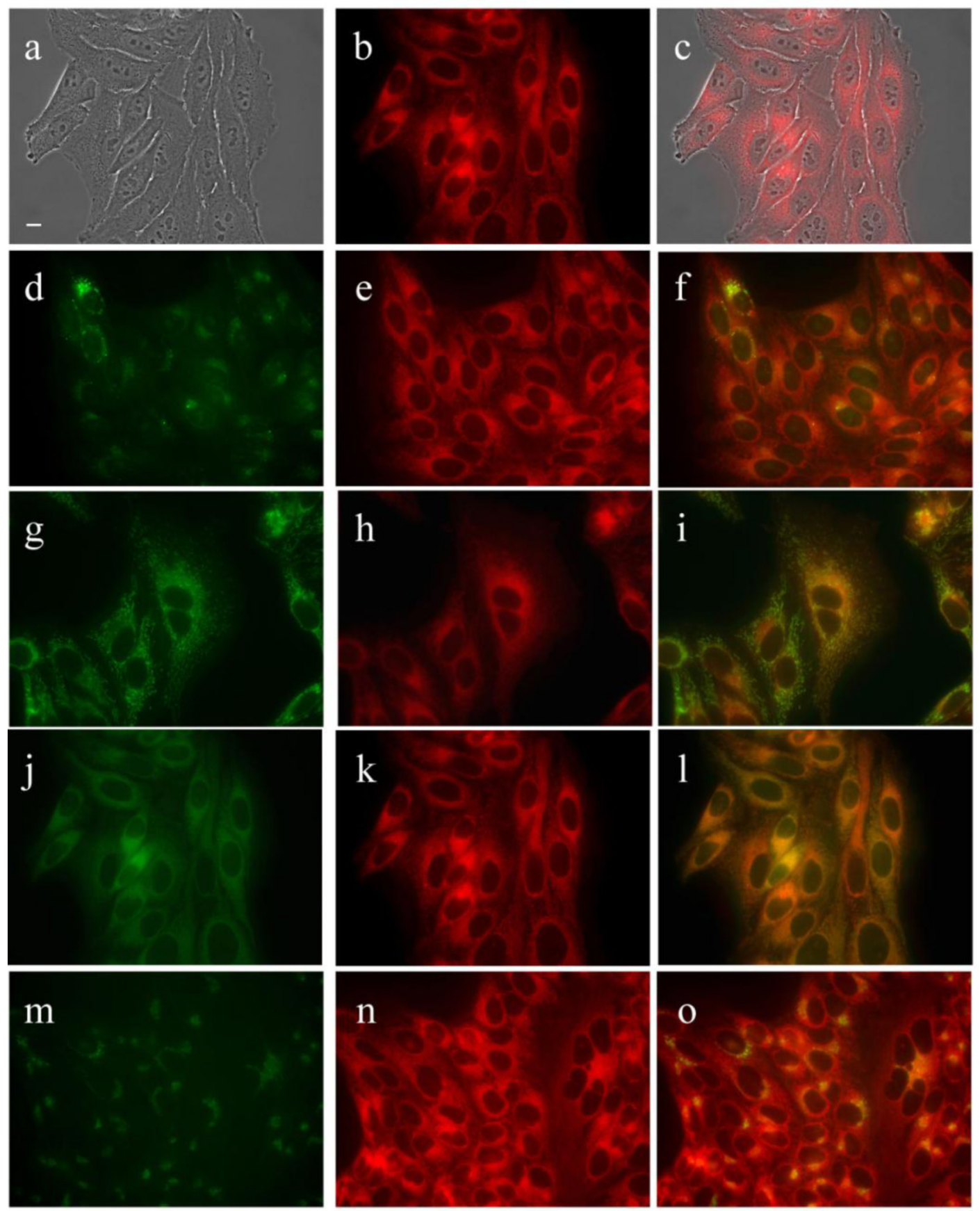

Figure 6.

Subcellular localization of MAP in HEp2 cells at $10 \mu \mathrm{M}$ for $18 \mathrm{~h}$. (a) Phase contrast (b,e,h,k,n) MAP fluorescence; (c) overlay of phase and compound; (d) LysoSensor (f) LysoSensor-compound overlay; (g) MitoTracker; (i) MitoTracker-compound overlay (j) ERTracker; (1) ERTracker-compound overlay; (m) BODIPY Ceramide; (o) BODIPY Ceramide-compound overlay. Scale bar: $10 \mu \mathrm{m}$. 

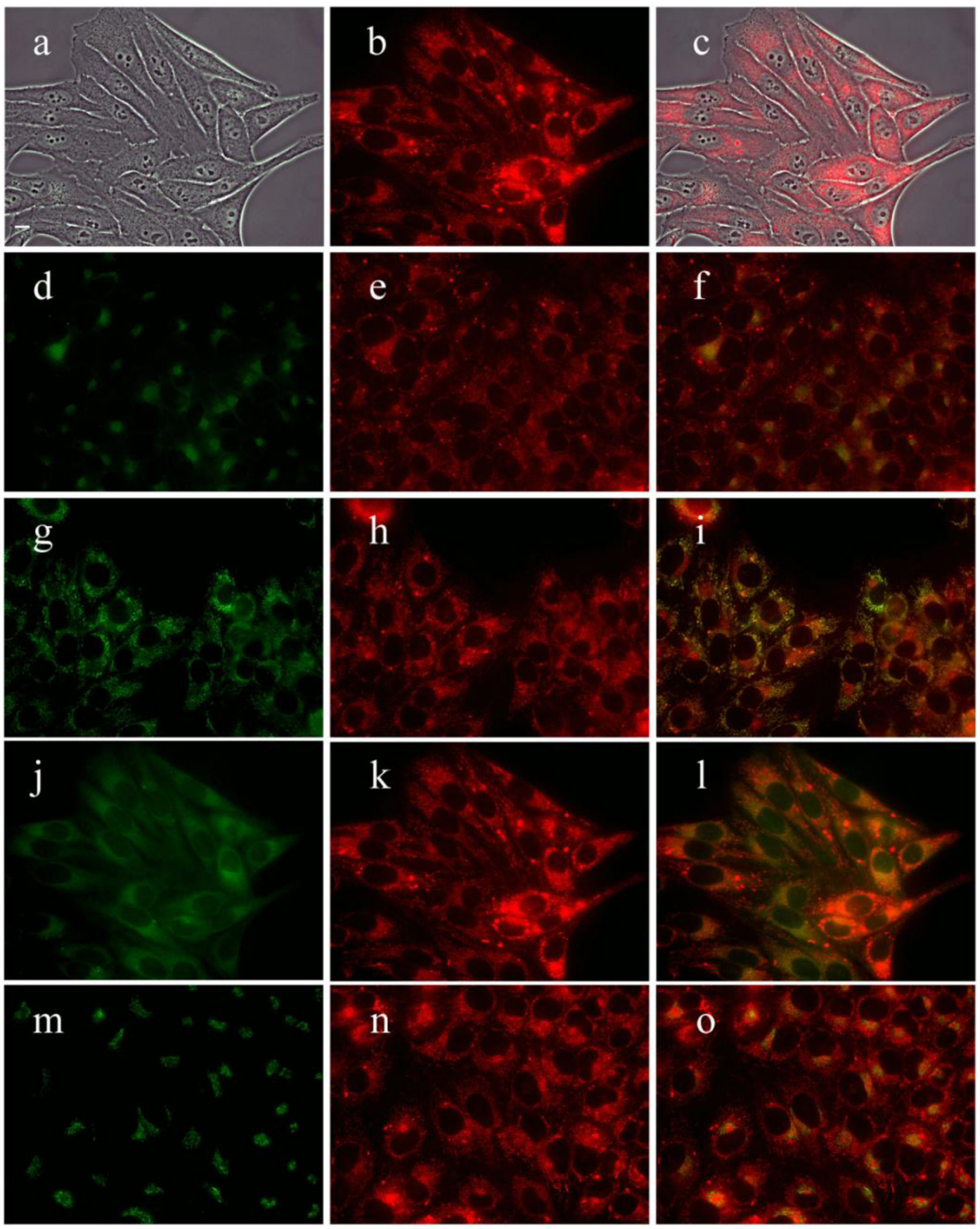

Figure 7.

Subcellular localization of DADP-a in HEp2 cells at $10 \mu \mathrm{M}$ for $18 \mathrm{~h}$. (a) Phase contrast (b,e,h,k,n) MAP fluorescence; (c) overlay of phase and compound; (d) LysoSensor (f) LysoSensor-compound overlay; (g) MitoTracker; (i) MitoTracker-compound overlay (j) ERTracker; (l) ERTracker-compound overlay; (m) BODIPY Ceramide; (o) BODIPY Ceramide-compound overlay. Scale bar: $10 \mu \mathrm{m}$. 

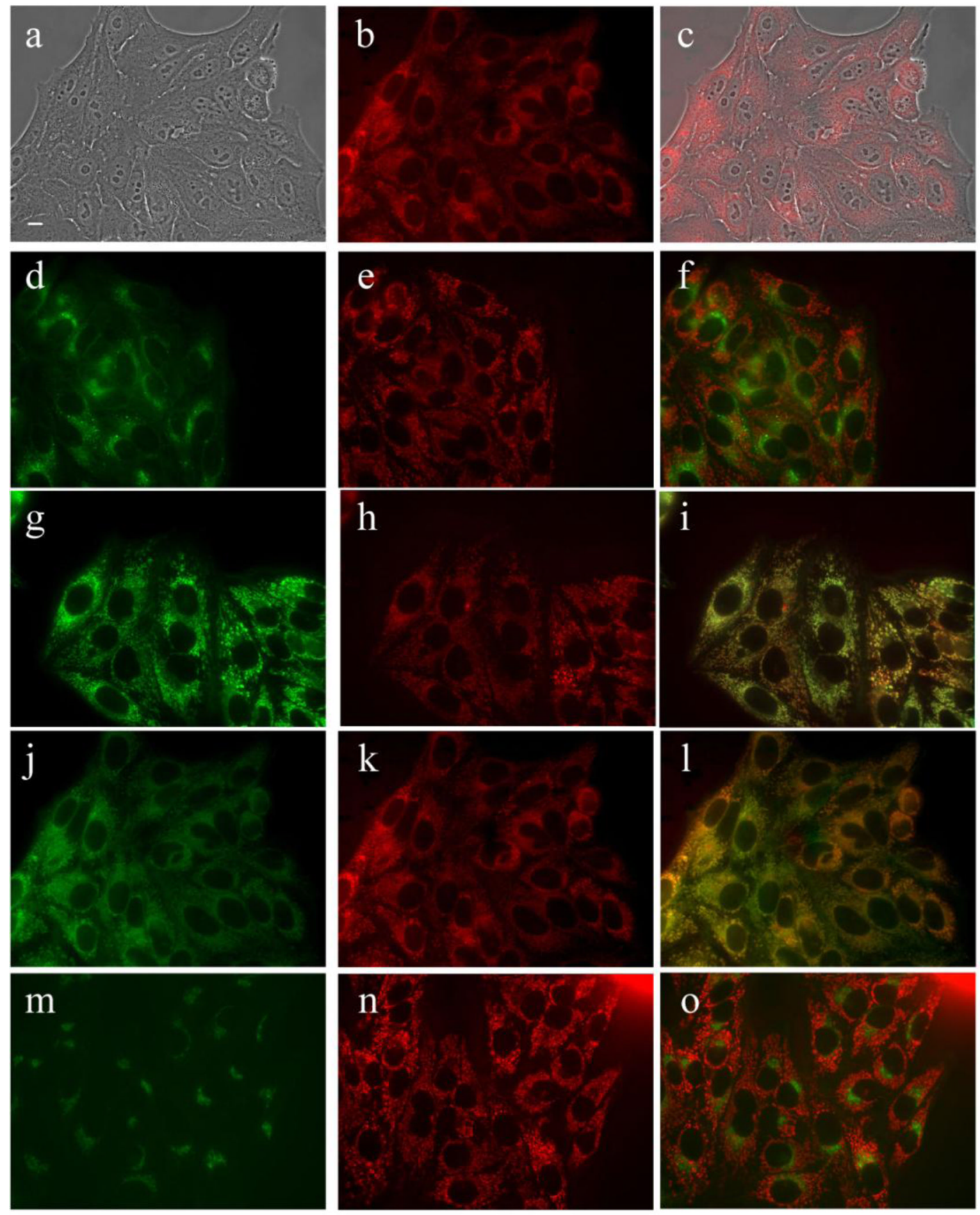

Figure 8.

Subcellular localization of DADP-o in HEp2 cells at $10 \mu \mathrm{M}$ for $18 \mathrm{~h}$. (a) Phase contrast (b,e,h,k,n) MAP fluorescence; (c) overlay of phase and compound; (d) LysoSensor (f) LysoSensor-compound overlay; (g) MitoTracker; (i) MitoTracker-compound overlay (j) DIOC6; (1) DIOC6-compound overlay; (m) BODIPY Ceramide; (o) BODIPY Ceramidecompound overlay. Scale bar: $10 \mu \mathrm{m}$. 

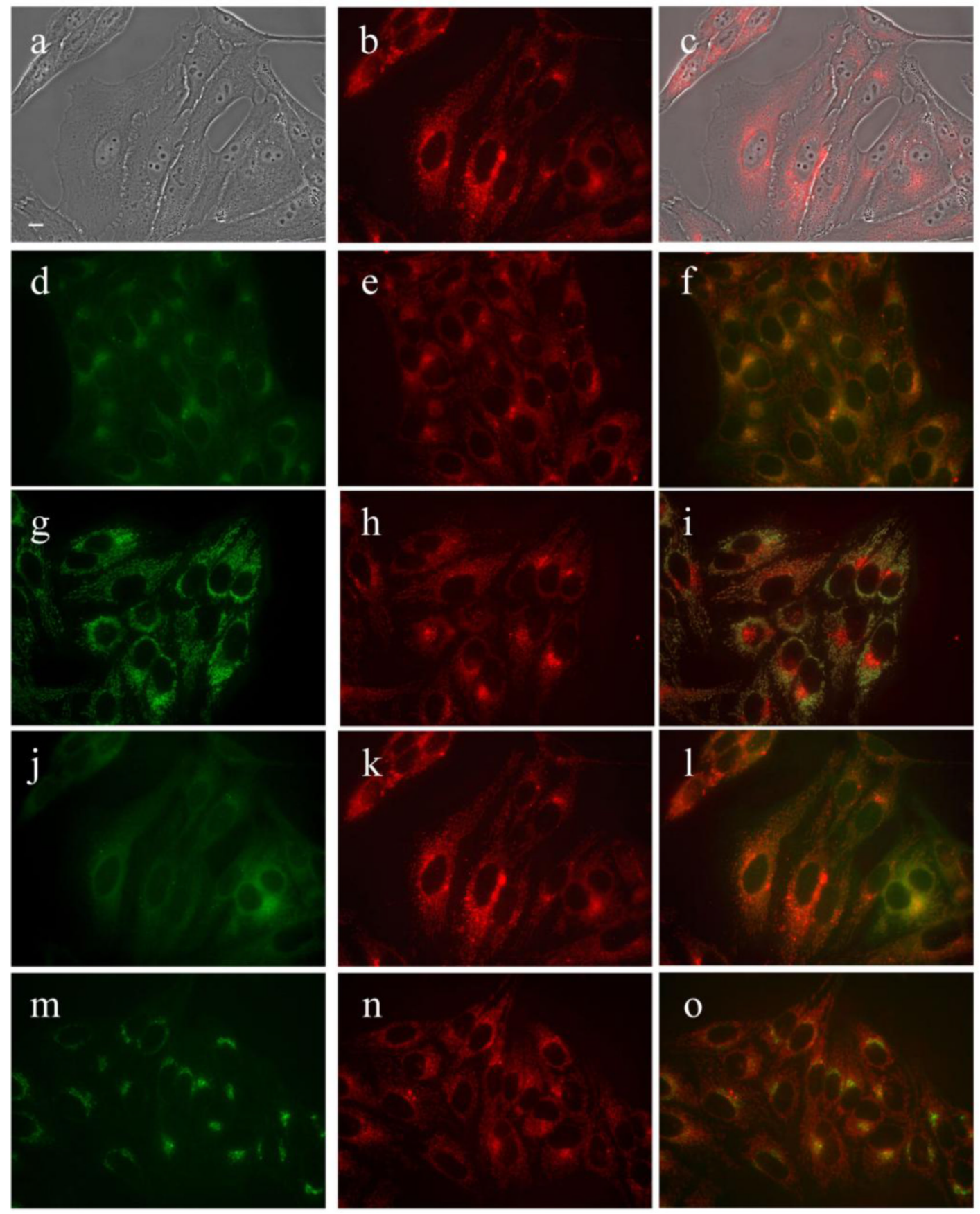

Figure 9.

Subcellular localization of TRAP in HEp2 cells at $10 \mu \mathrm{M}$ for $18 \mathrm{~h}$. (a) Phase contrast (b,e,h,k,n) MAP fluorescence; (c) overlay of phase and compound; (d) LysoSensor (f) LysoSensor-compound overlay; (g) MitoTracker; (i) MitoTracker-compound overlay (j) ERTracker; (l) ERTracker-compound overlay; (m) BODIPY Ceramide; (o) BODIPY Ceramide-compound overlay. Scale bar: $10 \mu \mathrm{m}$. 

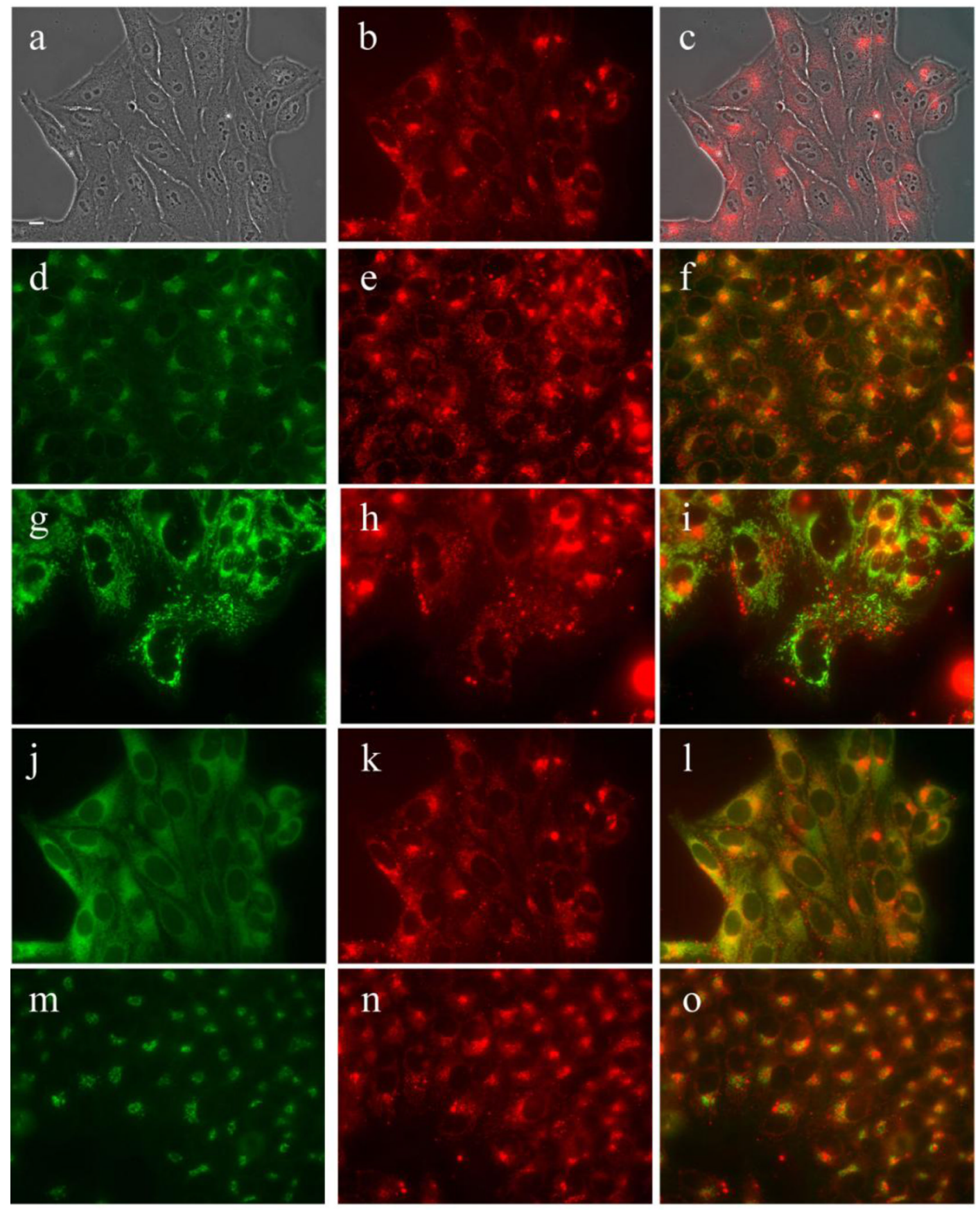

Figure 10.

Subcellular localization of TEAP in HEp2 cells at $10 \mu \mathrm{M}$ for $18 \mathrm{~h}$. (a) Phase contrast (b,e,h,k,n) MAP fluorescence; (c) overlay of phase and compound; (d) LysoSensor (f) LysoSensor-compound overlay; (g) MitoTracker; (i) MitoTracker-compound overlay (j) DIOC6; (1) DIOC6-compound overlay; (m) BODIPY Ceramide; (o) BODIPY Ceramidecompound overlay. Orange yellow color in overlay indicates colocalization. Scale bar: 10 $\mu \mathrm{m}$. 


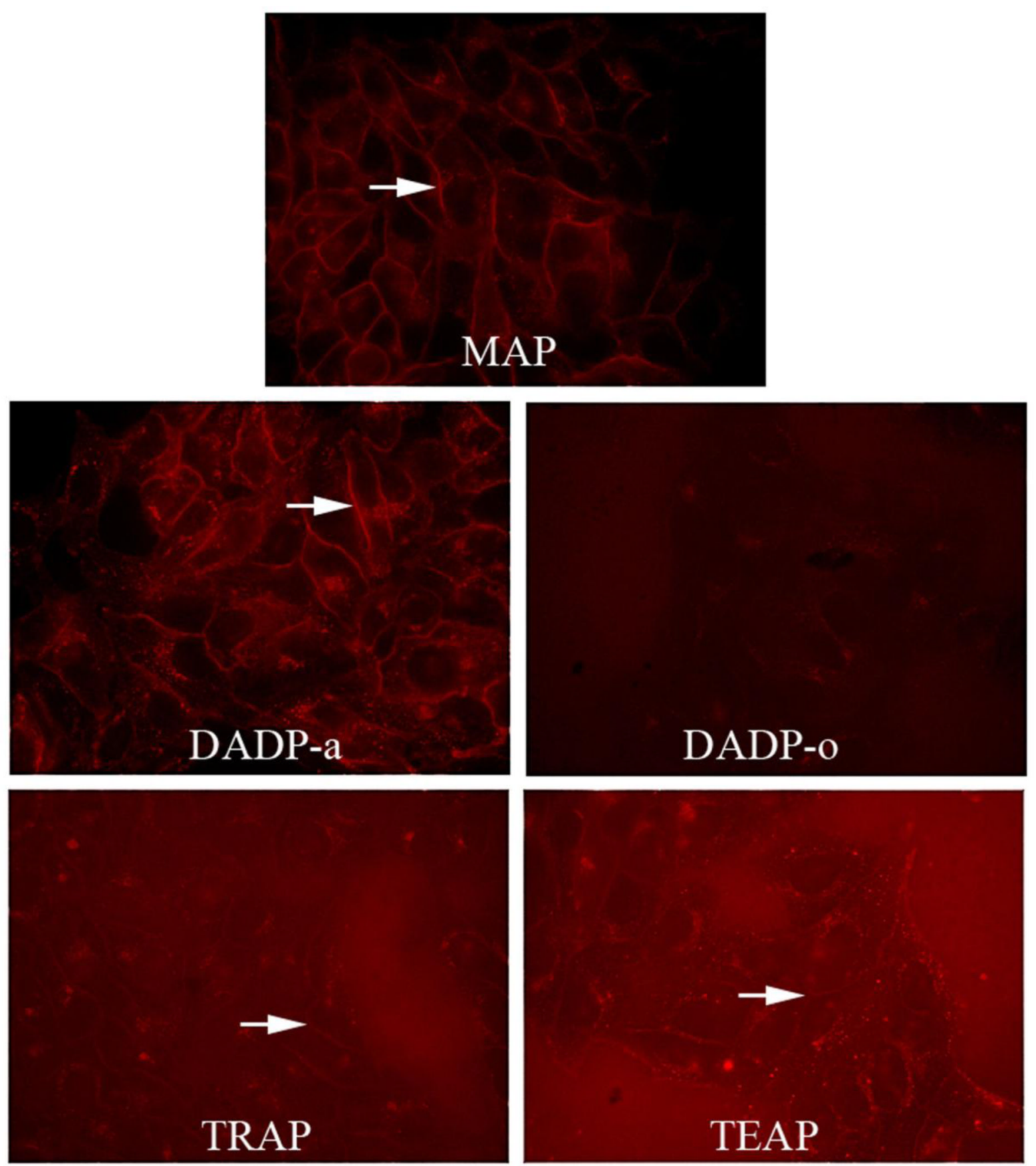

Figure 11.

Short (30 minute) exposure of HEp2 cells to porphyrins reveals the compound associating with plasma membrane (arrows) in all cases except DADP-o. The low contrast of these images is due to the short uptake time and low amount of compound that was able to accumulate. 